\title{
Heavy metals contaminants in the eggs and temperatures of nesting beaches of sea turtles in Kaimana, West Papua, Indonesia
}

\author{
RICARDO F. TAPILATU ${ }^{1,2,}$, HENGKI WONA ${ }^{1}$, RIMA HS. SIBURIAN ${ }^{1,3}$, SEFRIANTO T. SALEDA $^{4}$ \\ ${ }^{1}$ Research Centre of Pacific Marine Resources, Universitas Papua. J1. Gunung Salju, Amban, Manokwari 98314, West Papua, Indonesia. \\ Tel./fax.: +62-986-211430, `email: rf.tapilatu@unipa.ac.id \\ ${ }^{2}$ Department of Marine Science, Faculty of Fisheries and Marine Science, Universitas Papua. Jl. Gunung Salju, Manokwari 98314, West Papua, Indonesia \\ ${ }^{3}$ Department Silviculture, Faculty of Forestry, Universitas Papua. J1. Gunung Salju, Manokwari 98314, West Papua, Indonesia \\ ${ }^{4}$ Conservation International (CI) Indonesia. Jl. Imam Bonjol No. 9, Wagom Utara, Pariwari, Fakfak 98651, West Papua, Indonesia
}

Manuscript received: 5 August 2020. Revision accepted: 11 September 2020.

\begin{abstract}
Tapilatu RF, Wona H, Siburian RHS, Saleda ST. 2020. Heavy metals contaminants in the eggs and temperatures of nesting beaches of sea turtles in Kaimana, West Papua, Indonesia. Biodiversitas 21: 4582-4590. Etna Bay and Venu Island in Kaimana, West Papua, Indonesia are two of many areas that sea turtles use during the nesting season. Here, we report data on heavy metals contaminants from a sample of eggs of green (Chelonia mydas) and hawksbill (Eretmochelys imbricata) turtles collected from a subset of two nests during the 2016 nesting season at Venu Island, Kaimana, West Papua, Indonesia. Three heavy metals contaminants (i.e. mercury, cadmium, arsenic) found in eggs exceeded the established safety limits for human consumption. Other contaminants such as lead, zinc, manganese, iron, and copper were found below the established safety standards. There is an implication of the containment of heavy metals in sea turtle eggs to human health in Kaimana when it is consumed. It is highly recommended that the harvesting of turtle eggs and adults of all of sea turtles at Kaimana be totally prohibited. In addition, overall, beach temperatures in Lakahia fluctuated at a larger range between $26.5^{\circ}$ and $33.8^{\circ} \mathrm{C}$ than at Venu island that fluctuated between $25.9^{\circ}$ and $30.2^{\circ} \mathrm{C}$. Mean daily temperatures of in-situ nests during the middle third of the incubation period were above the pivotal temperature of $29.0^{\circ} \mathrm{C}$ for temperature-dependent sex determination suggesting a female bias may already exist. The chemical contamination found in the eggs of $C$. mydas and E. imbricata at Venu Island is thought to assist sea turtle conservation initiatives in the area. The conservation program at the prime nesting habitat for green and hawksbill turtles on the small islands west of Kaimana such as Venu Island should be intensified to reverse the decline and increase population size of nesting sea turtle species. It is recommended that education and outreach be implemented in surrounding communities in Kaimana to raise awareness about marine turtle conservation.
\end{abstract}

Keywords: Beach temperatures, contaminants, food consumption, in situ nests, sea turtle egg

\section{INTRODUCTION}

Etna Bay and Venu Island in Kaimana, West Papua, Indonesia are two of many areas that sea turtles use during the nesting season. Anecdotal evidence from the reports of local villagers suggests the presence of leatherback turtles (Dermochelys coriacea) in the waters of Etna Bay and nesting on the adjacent beach. These seasonal sightings indicate that Etna Bay and Venu Island might be important nesting and inter-nesting areas for leatherbacks turtle and other turtle species, such as endangered olive-ridley (Lepidochelys olivacea), green (Chelonia mydas) and critically endangered hawksbill turtle (Eretmochelys imbricata) turtles.

While the presence of sea turtles in Etna Bay is a good indication of their existence in the area, they likely face a great risk of being harvested at other nesting beaches situated along the coast of the Bird's Head Seascape (Tapilatu et al. 2017; Tapilatu unpublished report), because of the proximity to human settlements. Data on leatherback and other marine turtle nesting activity on non-indexed beaches are scarce. The term non-index beaches are used to refer to beaches or sites where nesting activity is in lowerintensity (Santidrian-Tomillo et al. 2017). These data are critical for assessing the overall status of the Bird's Head
Seascape nesting population and ensuring that sea turtle populations have adequate protection at non-indexed beaches. More importantly, the data will help in developing a region-wide sea turtle conservation and management strategy to reverse population decline as indicated by the decline of leatherback on the north coast of Bird's Head Peninsula (Tapilatu et al. 2013) and other sea turtle populations in the north coast of Manokwari (Tapilatu 2017).

In recent years, the protection of sea turtles in Indonesia had increased at the index nesting beaches. Due to lack of enforcement, harvesting of turtle eggs had often occurred and contributed as one of the major factors to the decline of sea turtle nesting such as at Bird's Head Seascape. Furthermore, the presence of illegal egg collectors had resulted to high number of eggs being sold in the local markets including Kaimana. A few studies had reported that sea turtles are affected from toxic contaminants (Sakai et al. 1995; Godley et al. 1999) due to their long-lived characteristic with vast migration areas, thus increase their chances of being exposed to environmental toxicants and are able to accumulate a variety of contaminants over multiple years. Worldwide, waste from various industrial, agricultural, and human activities was easily disposed into the sea without proper treatments. Most of the waste 
contains toxic metals compositions would accumulate in the marine environments including habitat of sea turtles. Moreover, feeding behavior would also influence the accumulation of heavy metals in sea turtles. The diets of green turtle are mainly consisting of marine algae and seagrasses, which are known to have the ability to accumulate heavy metals (Khristoforova and Kozhenkova 2002). These heavy metals would also be transferred from the mother to offspring by their eggs. Essential metals are used in the development of the embryo within the eggs. In similar way, toxic metals including mercury, lead, and cadmium, even in limited amounts would be transferred. Non-essential and essential metals are able to act as toxicants at high concentrations in organisms (Kobayashi and Okamura 2004). In addition to the inorganic elements, the environmental conditions at the nesting beaches are a major determinant of incubation temperature. Even within a rookery, there must be some variation in incubation temperature. As such, it is of interest to evaluate naturally heavy metal contaminants and occurring sex ratios in sea turtle populations in Kaimana. The two components of this study are important for both conservation of sea turtles and for public health awareness in Kaimana.

The government of Kaimana District, West Papua Province has engaged the Research Centre of Pacific Marine Resource (RC-PMR), University of Papua (UNIPA), to implement a research project to obtain the necessary data and engage the local community. The research aimed to: (i) identify the presence of heavy metals contaminants in the eggs of two sea turtle species, i.e. C. mydas and E. imbricata, and (ii) profile the temperature of the beach and nest. The first aim has particular importance to inform the potential health risks if the eggs are being consumed by human, while the second aim is critical to estimate occurring sex ratios in the context of management and conservation. The planned outcome of this survey was to bring this information in the form of recommendations to the Kaimana government so they can develop an appropriate marine turtle management plan. Our work will fill an important knowledge gap in describing the regional threats to sea turtles and their nests, information that is critical for directing conservation initiatives.

\section{MATERIALS AND METHODS}

\section{Study area and period}

This study took place on Lakahia and Venu Island (Figure 1) of Kaimana, West Papua, Indonesia during the 2016 sea turtles nesting season. Lakahia is a village on an island and adjacent area close to the village on the mainland is also called Lakahia. Administratively, Venu Island is included in the area of Adijaya village, Buruway District, Kaimana Regency. Venu Island is designated as a Marine Wildlife Reserve based on the Decree of the Minister of Forestry and Plantation Republic of Indonesia No. 891/KptsII/1999 since October 14, 1999. It has an area of 16320.00 ha and is under Management of Technical Implementation Unit (UPT) of Natural Resources Conservation Agency (BKSDA) West Papua. Beach and nest temperatures were monitored between March and September 2016. During the visit in March, sample of sea turtle eggs was collected by research team. To avoid eggs poaching, the exact locations of nests are not explicitly mentioned.

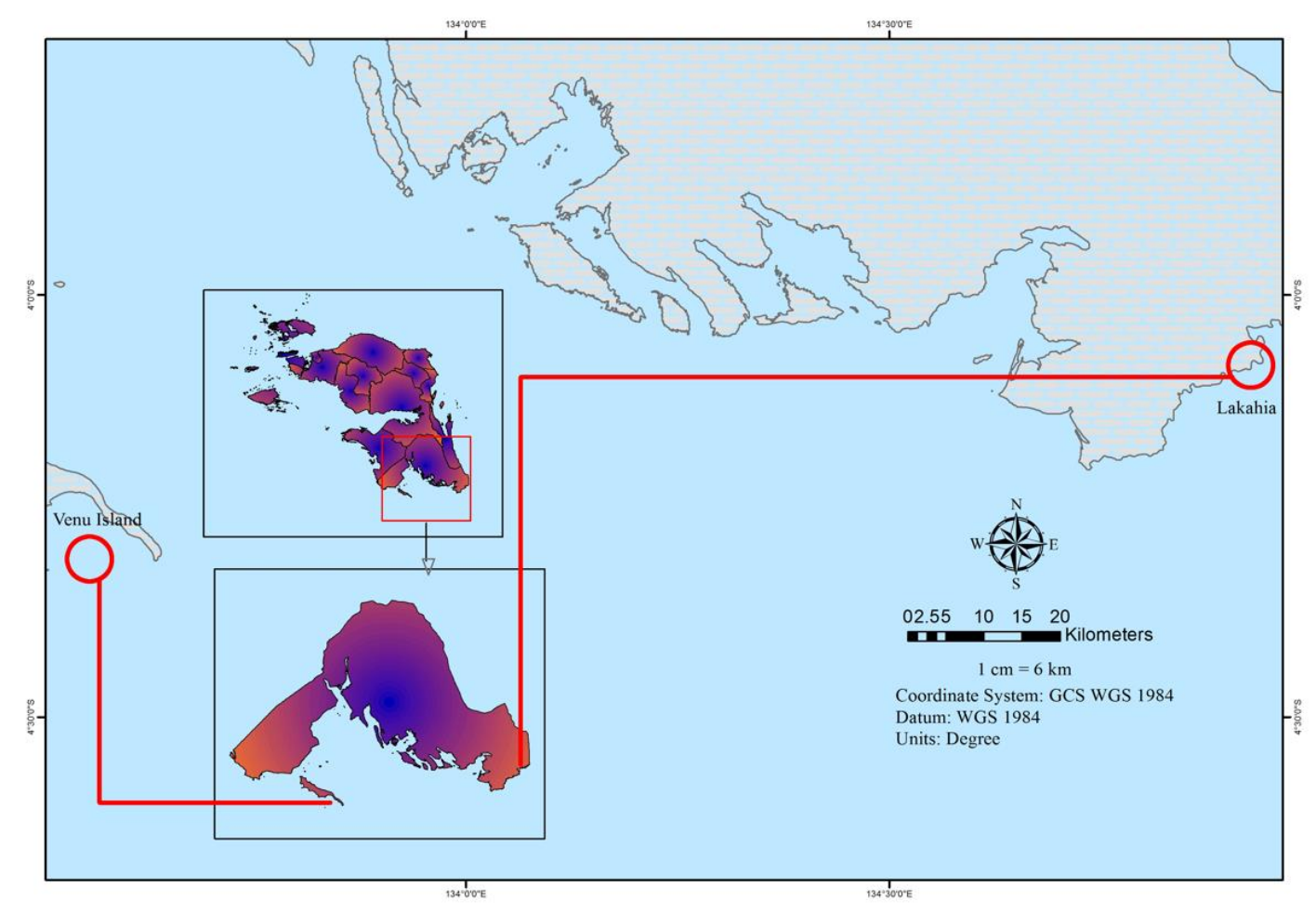

Figure 1. Map of study area in Lakahia and Venu Island, Kaimana, West Papua, Indonesia 


\section{Heavy metals contaminants}

Large scale inorganic elements studies of sea turtle eggs have often been avoided because they require the sacrifice of eggs in a threatened or endangered population (Sakai et al. 1995). In March 2016, fresh sea turtle eggs were randomly collected from recently laid nests of green $(C$. mydas) and hawksbill (E. imbricata) sea turtles to be analyzed for heavy metal contaminants (Table 1). Due to protection status of sea turtles in Indonesia, only a few eggs were permitted to be taken. Three eggs were collected from each nest and stored in a refrigerator at the Research Centre of Pacific Marine Resources, University of Papua (UNIPA) in Manokwari. The eggs were then shipped to ProLing Laboratory, Faculty of Fisheries and Marine Science, Bogor Agricultural University. This lab is an accredited environmental laboratory in Bogor, West Java for heavy metals analysis. The analysis was undertaken by using the American Public Health Association (APHA) 2012 Protocols on Metals by cold-vapor atomic absorption spectrometry: Mercury (3112-B, 3030-E); Cadmium, Lead, Zinc, Manganese, and Copper (3111-B, 3030-E); Arsenic (3114-B, 3030-E); and Iron (3500-Fe-B).

\section{Beach and nest temperature monitoring}

A type of temperature data logger (Hobo Water Temp Pro, Onset Computer Corporation, Pocasset, MA) was used to record sand and nest temperatures. The datalogger accurately recorded temperatures to approximately \pm 0.3 $0.4^{\circ} \mathrm{C}$. The data loggers were calibrated and programmed in the Research Center of Pacific Marine Resources at UNIPA Manokwari to record the temperature every hour during the main nesting season (March-September 2016) in the boreal summer season in Lakahia and Venu Island, Kaimana.

Generally, the formation of the beaches includes an intertidal zone, then a sloping zone, followed by a vegetative dune. The majority of turtle nesting activity typically occurs well above the high tide line within the sloping zone of the beach. In order to monitor beach temperatures, a temperature transect running from the high-tide line to the vegetation was evaluated. Two data loggers were buried at: 1) the upper portion of the open beach area, approximately 2 to $3 \mathrm{~m}$ from the vegetation line and 2) the lower beach zone, approximately 3 to $5 \mathrm{~m}$ from the high-tide line. Meanwhile, due to the small size of Venu Island, two data loggers were placed on east and west sides of the island in the upper beach area. The dataloggers were placed at a depth of $60 \mathrm{~cm}$, which was selected to approximate the bottom depth of green turtle and hawksbill nests.

In addition, a temperature data logger was also used to record incubation temperatures of in-situ nests at Venu Island. The datalogger was placed in the center of the nest when a female sea turtle was encountered during nesting. The mean nest temperature during the middle third of the incubation period was calculated for the nest and compared to the pivotal temperature for green and hawksbill turtles to assess the effect of nest temperature on estimated hatchling sex ratio. The mean nest temperature during the middle third of incubation period represents an accurate method for predicting sex ratio in nests that do not experience large daily fluctuations in temperature (Georges et al. 1994; Georges et al. 2004). Additionally, it has recently been suggested that calculations regarding the middle third of incubation should be based on developmental rates taking into account daily temperature fluctuations, rather than being based on the total incubation duration (Girondot 2014). In nests with minimal daily temperature fluctuation, incubation of the middle third based on the total incubation period should approximate incubation in the middle third based on developmental rates.

\section{Beach and incubation temperature data analysis}

The beach temperature data were downloaded using HOBOWARE software and exported to Microsoft Excel. The hourly sand temperatures were averaged to obtain mean daily sand temperatures. Sand temperatures were compared between the upper and lower beach zones at Lakahia and compared between west and east sections of the beach in Venu Island using a Mann-Whitney test. An IBM SPSS Statistic 20 was used to analyze data.

To model the thermal reaction norm of embryonic development, nest temperature traces from the time of oviposition to the time of emergence were used using the Rpackage, embryo growth (5.2, http://cran.r-project.org) (Girondot and Kaska 2014) in R version 3.1 (R Core Team 2018). Meanwhile, to determine the TSP duration, the middle third of development for each nest was estimated from the model of embryonic growth. Consequently, sex ratio of hatchling produced was estimated by the mean temperature, weighted by embryonic growth, during the middle third of development for each nest $\left(\mathrm{CTE}_{\mathrm{W}}\right)$.

\section{RESULTS AND DISCUSSION}

\section{Heavy metals contaminants}

In total, 6 sea turtle eggs were analyzed for heavy metals contaminants. In total, 8 elements were detected (Table 1). The mercury, cadmium, and arsenic content found in all eggs exceeded safety limits for human consumption, 0.5 $\mathrm{mg} / \mathrm{kg}$ (Table 1, Tapilatu et al. 2016; 2020). Other heavy metals, such as lead, zinc, manganese, iron, and copper, were present, but at concentrations below the established safety standard (Table 1).

\section{Beach temperatures}

Overall, beach temperatures in Lakahia fluctuated between $26.5^{\circ}$ and $33.8^{\circ} \mathrm{C}$ (Table 2). A significant difference in daily mean beach temperature recorded between the upper and lower beach zones was detected in Lakahia (paired $t$ test; $t=-3.59, p=0.008$ ) in which the lower beach zone was warmer than the upper beach zone. Furthermore, mean beach temperatures differed among months at both zones (ANOVA; $\mathrm{F}=12.83, p<0.05$ ), with temperatures in March being significantly warmer than other months (AprilSeptember; Scheffe's; $p<0.05$ ). 
Table 1. Assessment of heavy metals contaminants in a subset sample of sea turtle eggs collected from nests at Venu Island, Kaimana, West Papua, Indonesia

\begin{tabular}{lcccl}
\hline \multicolumn{1}{c}{ Parameter } & $\begin{array}{c}\text { Detection } \\
\text { limit }\end{array}$ & $\begin{array}{c}\text { Subset sample green turtle } \\
\text { eggs (unit: } \mathbf{~ m g / k g})\end{array}$ & $\begin{array}{c}\text { Subset sample hawksbill turtle } \\
\text { eggs (unit: } \mathbf{~ m g} / \mathbf{k g})\end{array}$ & \multicolumn{1}{c}{ Analysis method } \\
\hline Mercury $(\mathrm{Hg})$ & 0.004 & $0.421^{*}$ & $0.326^{*}$ & APHA, 2012 3112-B, 3030-E \\
Cadmium (Cd) & 0.40 & $2.12^{*}$ & $2.31^{*}$ & APHA, 2012 3111-B, 3030E \\
Arsenic (As) & 0.003 & $0.875^{*}$ & $0.569^{*}$ & APHA, 2012 3114-B, 3030E \\
Lead (Pb) & 0.23 & $<0.23$ & $<0.23$ & APHA, 2012 3111-B, 3030-E \\
Zinc (Zn) & 0.67 & 70.36 & 58.83 & Same above \\
Manganese (Mn) & 0.53 & $<0.53$ & 0.80 & Same above \\
Copper (Cu) & 1.2 & 4.33 & 3.65 & Same above \\
Iron (Fe) & 5.00 & 15.65 & 42.78 & APHA, 2012 3500-Fe-B \\
\hline
\end{tabular}

Note: ${ }^{*}$ Exceeding safety limits (Tapilatu et al. 2016; 2020)

Table 2. Mean daily beach temperature $\left({ }^{\circ} \mathrm{C}\right)$ at $60 \mathrm{~cm}$ at lower and upper beach zones in Lakahia recorded from 11 March-30 September 2016

\begin{tabular}{lcccc}
\hline \multirow{2}{*}{ Month } & \multicolumn{2}{c}{ Upper zone } & Lower zone \\
\cline { 2 - 5 } & Mean \pm sd & Temperature range & Mean \pm sd & Temperature range \\
\hline March & $31.5 \pm 0.5$ & $30.4-32.2$ & $32.8 \pm 0.6$ & $31.8-33.8$ \\
April & $29.9 \pm 0.5$ & $29.1-30.9$ & $31.7 \pm 0.6$ & $30.6-32.6$ \\
May & $30.6 \pm 0.3$ & $30.1-31.2$ & $32.7 \pm 0.4$ & $31.8-33.5$ \\
June & $29.6 \pm 0.8$ & $28.0-30.5$ & $32.1 \pm 0.7$ & $30.7-32.9$ \\
July & $28.0 \pm 0.4$ & $27.4-28.8$ & $30.0 \pm 0.7$ & $29.0-31.4$ \\
August & $27.9 \pm 0.9$ & $26.5-29.5$ & $29.3 \pm 0.9$ & $28.0-30.9$ \\
September & $30.1 \pm 0.9$ & $28.7-31.7$ & $31.3 \pm 1.1$ & $29.8-33.2$ \\
\hline
\end{tabular}

Table 3. Mean daily beach temperature $\left({ }^{\circ} \mathrm{C}\right)$ at $60 \mathrm{~cm}$ at eastern and western beach sections in Venu Island recorded from $12 \mathrm{March}-12$ September 2016

\begin{tabular}{lcccc}
\hline \multirow{2}{*}{ Month } & \multicolumn{3}{c}{ Eastern section } & Western section \\
\cline { 2 - 5 } & Mean \pm sd & Temperature range & Mean \pm sd & Temperature range \\
\hline March & $30.0 \pm 0.1$ & $29.6-30.2$ & $29.2 \pm 0.4$ & $26.1-29.7$ \\
April & $28.5 \pm 0.4$ & $27.8-29.3$ & $27.6 \pm 0.5$ & $26.3-29.3$ \\
May & $28.3 \pm 0.2$ & $27.8-28.7$ & $28.5 \pm 0.6$ & $27.1-29.1$ \\
June & $28.4 \pm 0.2$ & $27.8-28.7$ & $28.4 \pm 0.5$ & $26.7-28.1$ \\
July & $27.3 \pm 0.5$ & $25.9-27.8$ & $27.6 \pm 0.4$ & $26.7-28.1$ \\
August & $26.6 \pm 0.4$ & $26.0-27.3$ & $27.3 \pm 0.4$ & $27.3-27.9$ \\
September & $26.9 \pm 0.2$ & $26.7-27.2$ & $27.7 \pm 0.2$ & \\
\hline
\end{tabular}

Overall, beach temperatures in Venu Island fluctuated between $25.9^{\circ}$ and $30.2^{\circ} \mathrm{C}$ (Table 3 ). A significant difference in daily mean beach temperature monitored between eastern and western beach sections was detected in Venu Island (paired $t$-test; $t=-2.59, p=0.04$ ) in which overall the western section was warmer than the eastern section. In addition, mean beach temperatures differed among months at both zones (ANOVA; $\mathrm{F}=9.83, p<0.05$ ), with temperatures in March being significantly warmer than other months (AprilSeptember; Scheffe's; $p<0.05$ ).

\section{Beach and incubation temperatures at Venu Island}

The profiles of nest temperatures were grouped into three distinct phases: early, heating, and cooling (Figure 2). During March-April 2016, nest temperatures are likely to track the beach temperature at $60 \mathrm{~cm}$ for the early portion of incubation and then increase around $2-3^{\circ} \mathrm{C}$ above beach temperature at the third-trimester portion (Figure 2). The increase in incubation temperatures was relatively smooth with temperature changes within any given week being < $0.9^{\circ} \mathrm{C}$.

Changes in incubation temperatures over a period of a few days were probably because of environmental parameters, such as rainfall. Nest temperature ascended slightly so that during the middle incubation period, incubation temperatures were $2-3^{\circ} \mathrm{C}$ distinctively warmer than the beach temperature. A rise in incubation temperature warmer than the surrounding beach temperature during the middle portion of incubation had been reported in sea turtle nests (Booth and Astill 2001; Broderick et al. 2001; Godley et al. 2002). This phenomenon is a result of the metabolic heat produced by developing embryos that increase significantly during the end stages of the incubation period. During the early phase, nest temperatures generally tracked 
the beach temperatures at $27^{\circ} \mathrm{C}$ while the majority of nests initiated at $29^{\circ} \mathrm{C}$. Furthermore, mean incubation temperatures recorded in the current study were typically above the pivotal temperature (PT, Figure 2) that has been reported for green turtles, such as in Costa Rica with $28^{\circ} \mathrm{C}$ (Morreale et al. 1982), the Mediterranean with $29^{\circ} \mathrm{C}$ (Kaska et al. 1998), and tend to average around $29^{\circ} \mathrm{C}$ (Mrosovsky 1988) in all sea turtles.

A female-biased sex ratio was estimated by the mean temperature during the middle third of development regardless of whether temperatures were weighted by embryonic growth or time. However, the mean temperature of nests during the TSP weighted by embryonic growth was higher $\left(32.14^{\circ} \mathrm{C} \pm 0.69\right)$ than when weighted by time $\left(31.71^{\circ} \mathrm{C} \pm 0.59\right)$. In addition, a female-biased sex ratio was also predicted for all but one nest when TSP length in this study was compared to TSP length where hatchling sex ratios were known (Miller and Limpus 1981). Therefore, it would be possible that a few intersex individuals may have been produced in these nests; however, the expected overall sex ratio would remain female-biased.

\section{Discussion}

Heavy metals contaminants in sea turtle eggs and the risks to human health

This study determined the presence of certain metals elements. A study by Cortez-Gomez et al. (2018) on wild populations of olive-ridley turtles detected 7 inorganic elements such as arsenic, cadmium, copper, nickel, lead, selenium, and zinc. In addition, this study indicated that the mean concentration of heavy metals in sea turtle eggs has exceeded the threshold for heavy metals for egg products set by the Food and Drug Administration (FDA) Regulation No.5 of 2018. For example, the threshold for cadmium is 0.1 $\mathrm{mg} / \mathrm{kg}$. In environmental assessments of heavy metals, cadmium and mercury warrant special attention because of their vast global distribution and high potential toxicity and carcinogenicity in humans. Data from numerous studies of these metals in sea turtles have indicated that their concentrations vary greatly by species, region, and tissue type. Cadmium, mercury, and lead have been documented in eggs and hatchlings of sea turtle in concentrations known to cause toxic effects in other vertebrates (Vazquez et al. 1996; Godley et al. 1999).

Mercury. The World Health Organization (WHO) has adopted the United States Environmental Protection Agency (EPA) standardized levels for mercury and recommends that food with mercury concentrations $>0.5 \mathrm{mg} / \mathrm{kg}$ should not be available for purchase. This suggests that the levels found in sea turtles (up to $8.15 \mathrm{ppm}$ or $\mathrm{mg} / \mathrm{kg}$ ) could be hazardous to human health. Long-range atmospheric transport of mercury can result in the contamination of aquatic systems in otherwise pristine areas (Ullrich et al. 2001). Mercury enters aquatic systems largely as inorganic mercury and is microbially transformed into methylmercury, which is a potent neurotoxin with a strong tendency to biomagnify within food chains. Humans are exposed to mercury predominantly through food consumption, with fish and shellfish as the main dietary sources of methylmercury. Methylmercury is found in highest concentrations in the muscle of marine biotas, and cooking increases the mercury content (EPA 2001). The mercury content found in sea turtle eggs in this study exceeds safety thresholds for human consumption (0.5 mg/kg, BSN 2009).

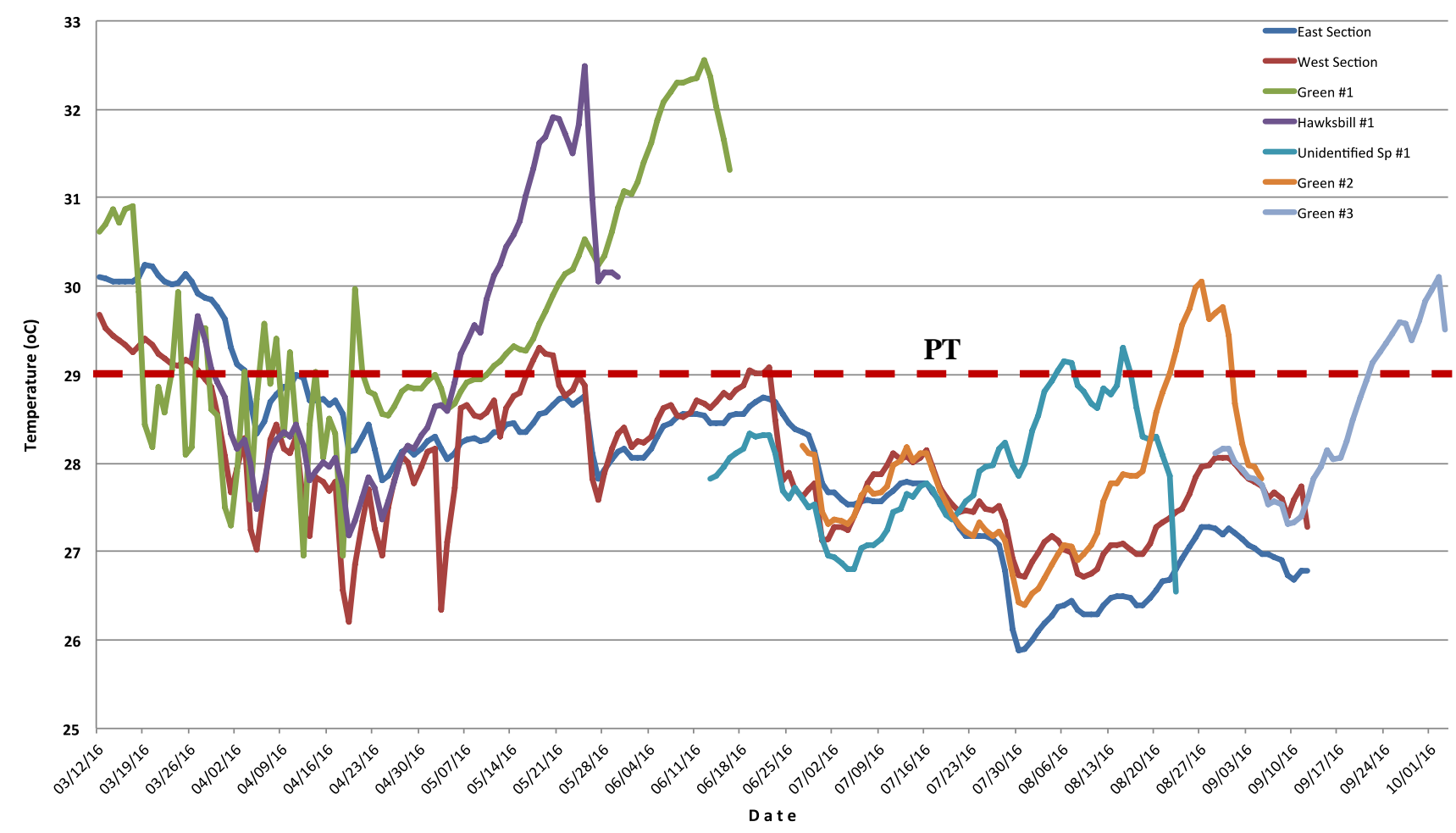

Figure 2. Profile of beach and nest temperatures at Venu Island, Kaimana, West Papua, Indonesia 
Mercury concentrations in sea turtles have been reported in a few studies from multiple locations such as in Europe $(0.39 \pm 0.04 \mathrm{lg} / \mathrm{g} \mathrm{dw}$ in liver; Davenport and Wrench 1990), in the Mediterranean (Storelli et al. 1998; median levels ranged from below detection level [BDL] to $2.41 \mathrm{lg} / \mathrm{g} \mathrm{dw}$ in Godley et al. 1999), and in Japan (mean of $1.51 \pm 2.93 \mathrm{lg} / \mathrm{g}$ wet weight in liver; Sakai et al. 1995) were higher than other seafood. Fetuses and infants appear to be at the highest risk for methylmercury toxicity in which methylmercury readily passes through the placenta and breast milk (Clarkson 1993; Grandjean et al. 1995). Human health risks assessments from methylmercury in fish using epidemiological studies indicated that even relatively low level of exposures may be harmful to fetuses (Clarkson 1990). Negative effects on the fetus (i.e. psychomotor retardation) would be estimated at daily intakes above $36 \mathrm{lg} \mathrm{Hg}$ /day for a $60 \mathrm{~kg}$ pregnant female (Clarkson 1990)-as such consumption of only $4 \mathrm{~g}$ of sea turtle tissue would exceed this level.

Cadmium. The maximum temporary tolerable weekly intake (PTWI) of cadmium recommended by WHO for people weighing $60 \mathrm{~kg}$ is $0.42 \mathrm{mg} / \mathrm{kg}(0.42 \mathrm{ppm})$ (WHO 2003). The mean cadmium concentration in most food ranges from 0.01 to $0.05 \mathrm{ppm}$ (WHO 2003); however, the high concentrations of cadmium found in sea turtle tissues (up to $652 \mathrm{ppm}$ ) exceed this level by over three orders of magnitude. Consequently, individuals with lower body weights, in particular children group, are at an increased risk of exceeding the PTWI. The cadmium levels found in sea turtle eggs in this study exceeded established safety standards for seafood products $(0.5 \mathrm{mg} / \mathrm{kg}, \mathrm{BSN} 2009)$ and may warrant concern for people who consume sea turtle tissue with high cadmium concentrations in the Kaimana region. In northwestern Mexico, the concentrations of cadmium measured in kidney tissue of green turtles (652 $\mathrm{lg} / \mathrm{g}$ dry weight $[\mathrm{dw}])$ and olive ridley turtles $(274 \mathrm{lg} / \mathrm{g} \mathrm{dw})$ were the highest reported for these species (Gardner et al. 2006). Elevated cadmium concentrations were also measured in sea turtles from Japan (mean of 39.4 $\pm 16.2 \mathrm{lg} / \mathrm{g}$ wet weight in Sakai et al. 1995) (Sakai et al. 2000; Anan et al. 2001), Europe (up to $243 \mathrm{lg} / \mathrm{g} \mathrm{dw}$ ) (Caurant et al. 1999), and Australia (mean of $28.3 \mathrm{lg} / \mathrm{g}$ wet weight) (Gordon et al. 1998). These concentrations are higher than the levels generally reported for other marine vertebrates (Beck et al. 1997; Cardellicchio et al. 2002; Mendez et al. 2002). In addition, Bicho et al. (2006) measured heavy metals in green turtle livers and eggs. The concentrations found in their study were higher than levels reported in other sites in the world. For example, $1408 \pm 814$ ppm wet weight for cadmium. Gordon et al. (1998) found that cadmium levels in the livers of stranded green turtles in Australia were higher significantly than the levels reported in commercial seafood products. In addition, heavy metal of cadmium detected in green turtle eggs was significantly high on Peninsular Malaysia with a concentration of $0.61 \mathrm{mg} / \mathrm{kg}$ (Joseph et al. 2014). Roe et al. (2011) examined the same thing in leatherback turtle (D. coriacea) in Playa Grande found cadmium concentrations between 0.3-1.6 mg/kg. Such studies indicate that heavy metals are not only found in the eggs of green and hawksbill turtles, but also those of leatherback turtles at other nesting beaches.

Arsenic. Arsenic levels found in sea turtle eggs in this study exceeded established safety standards for seafood products $(0.5 \mathrm{mg} / \mathrm{kg}, \mathrm{BSN} 2009)$ and may warrant concern for people who consume sea turtle tissue in the Kaimana region. In general, the high concentration of heavy metals ( $\mathrm{Hg}, \mathrm{Cd}$, and As) compared to the concentration of other inorganic elements in this study was thought to be because adult sea turtles in this area have ingested these metals and the eggs are contaminated through the sequestration process. According to Orłowski et al. (2017), the sequestration process is a process of eggshell transporter ions which should be useful for transferring one type of ion. However, because the presence of other similar ions, they would be inadvertently transferred to the eggshell via transporter ions.

In addition to significantly higher concentrations of heavy metals, other metal substances were found below the threshold. For example, lead detected in turtle eggs in Kaimana were lower than a study by Shintana et al. (1980) on eggs of olive ridley (L. olivacea) in Pariaman Beach with concentrations of heavy metal lead found in the range of 0.34-6.8 $\mathrm{mg} / \mathrm{kg}$, then in Joseph et al. (2014) who studied green turtle ( $C$. mydas) eggs on the coast of Peninsular Malaysia with the concentration of heavy metal lead found $9.46 \mathrm{mg} / \mathrm{kg}$.

\section{Nest temperatures}

The determination of primary sex ratios is critical in the scope of global climate change where populations of organisms with temperature-dependent sex determination (TSD) would be sexed with fluctuation in ambient temperature (Stubbs et al. 2014; dei Marcovaldi et al. 2016). Because empirical estimation of the in-situ sex ratio is logistically challenging, several proxies have been applied to estimate the main sex ratio of turtle populations worldwide (Girondot et al. 2010; Wyneken and Lolavar 2015). Considering thermal reaction norms for embryo developmental rates, at least three models had been developed for estimating sex ratios while calculating proxies. The model used in this study was $\mathrm{CTE}_{\mathrm{W}}$ (middle third of the incubation period) (Fuentes et al. 2017). This model has also been used by Stubbs et al. (2014) and Tapilatu and Ballamu (2015) in a sex ratio study of sea turtles.

It is well understood that the thermal tolerance for sea turtle embryos ranges between $25^{\circ}$ and $35^{\circ} \mathrm{C}$ (Ackerman 1997) or ranges between $24^{\circ}$ and $32^{\circ} \mathrm{C}$ (Yntema and Mrosovsky 1982). In addition, the pivotal temperatures tend to cluster around $29^{\circ} \mathrm{C}$ (Mrosovsky 1994). The pivotal temperature varies according to species and location. For example, the pivotal temperatures for leatherbacks were estimated at $29.25-30.50^{\circ} \mathrm{C}$ in Suriname and French Guiana (Mrosovsky et al. 1984; Dutton et al. 1985; Godfrey et al. 1996; Chevalier et al. 1999), in Malaysia (Chan and Liew 1995), and Costa Rica (Binckley et al. 1998). Meanwhile, pivotal temperature in laboratory conditions for green turtles on Ascension Island was $29.3^{\circ} \mathrm{C}$ (Tilley 2019). The beach temperatures observed at Venu Island and Lakahia may be 
within the thermal tolerance of turtle embryos, which results in the high hatching successes observed in clutches on Venu Island. The ideal sand temperature on both beaches could possibly be a contributing factor to the higher egg survival rates.

Mrosovsky (1994) states that sexual differentiation in sea turtles is strongly influenced by ambient incubation temperature or TSD. It has been shown specifically that the sustained temperature to which the embryo is exposed during the middle trimester of incubation determines the eventual gonadal differentiation and sex of the hatchling (Wibbels 2003). Overall mean beach temperatures at two beach sections in Venu Island in 2016 were typically near the pivotal temperature for sea turtles for the nesting season in 2016. In addition, in the sampled nests monitored with a datalogger, mean daily temperatures of in situ nests during the middle third period of the incubation period were above the pivotal temperature suggesting female-biased sex ratios. Thus, overall these results support the hypothesis that female-biased sex ratios may dominate in Venu Island. Female-biased sex ratios were also observed at other nesting beaches in the Bird's Head Seascape (Tapilatu and Tiwari 2007; Tapilatu 2014; Tapilatu and Ballamu 2015; Tapilatu 2017). The result revealed the impact of metabolic heating on incubation temperatures.

Nest temperature is determined by the surrounding temperature of the sand and the amount of metabolic heat from the developing embryo (Ackerman 1997). During the early part of the incubation period, the temperature of the nest is similar to the temperature of the surrounding sand. Then the metabolic heat production from the embryo begins to warm the nest above the surrounding sand temperature at the beginning of the last third of incubation. As such, the time of hatching the nest temperature is $0.25-2.95^{\circ} \mathrm{C}$ warmer than the beach temperature. A rise in incubation temperature above the surrounding beach temperature due to metabolic heat generated by the developing embryos during the last third of incubation duration is commonly reported in sea turtle nests. However, the increase in nest temperature due to metabolic heating may not affect sex ratios because sex is determined during incubation in the middle third period (Yntema and Mrosovsky 1982; Merchant-Larios et al. 1997; Wibbels 2003).

In conclusion, it is strongly recommended that the harvesting of turtle eggs and adults and juveniles of all four species of sea turtles at Kaimana be totally prohibited. The chemical contamination found in the eggs of $C$. mydas and E. imbricata at Venu Island is thought to assist sea turtle conservation initiatives in the area. The health risk from consumption of contaminated eggs has the potential to reduce the number of eggs illegally collected. A decrease in the number of harvested eggs may allow a stable or even an increase in sea turtle population in Kaimana. Despite the availability of sources of other animal protein (i.e. fish and deer) available to coastal communities in Kaimana, the cultural perception that turtle eggs are of high nutritional value has driven high consumption rates. One of the significant challenges in conserving sea turtles in Kaimana is to minimize the need for turtle eggs in a cultural context. This would be achieved by education and awareness programs that highlight the potential health risks of consuming sea turtle eggs, which contain high concentrations of toxic compounds. If implemented effectively, the programs are expected to reduce the collection of sea turtle eggs for human consumption and thus contribute significantly to sea turtle conservation in Kaimana.

In addition, conservation programs at the prime nesting habitat for green and hawksbill turtles on the small islands of Kaimana, such as Venu Island, should be intensified to reverse the decline and increase population size of all species of sea turtle species. Community support and involvement are crucial for lasting protection of marine turtles in Kaimana. It is recommended that education and outreach to raise awareness about the need for marine turtle conservation to be implemented in surrounding communities in Kaimana. Officers and community members in Kaimana were given materials to improve their understanding of sea turtle conservation. This activity will contribute to the development of an appropriate marine turtle management initiative for implementation by the Kaimana government.

Finally, to understand the connections between the foraging and nesting habitats and pelagic phase of sea turtles in Kaimana and their relationships to inorganic elements, future studies to seek the migration pathways and movement patterns using satellite transmitters are highly recommended. This would prove valuable in identifying priority habitat areas for oceanic marine-protected areas designed to protect the sea turtles during their pelagic migrations and in offshore mating and foraging habitats.

\section{ACKNOWLEDGEMENTS}

The following people and institutions provided help with logistics during fieldwork, editing, graphic and/or labwork: John Rumasukun, Thamrin Lamuasa, boat crews of Conservation International Indonesia-Kaimana Office, Stephanie K. Venables, Maryrose E. Tapilatu, and ProLing Laboratory-Faculty of Fisheries and Marine Science-Bogor Agricultural University in Bogor. Fieldwork was made possible through financial support of Department of Fisheries and Oceans (DFO)-Canada and Conservation International (CI) Indonesia. The funders had no role in the study design, data collection, and analysis, decision to publish, or preparation of the manuscript. We are very grateful for the support provided by the Kaimana Government with research permit No. 005/243-SEKDA. The research was fully approved by the University of Papua (UNIPA) granted by Ministry of Research, Technology, and Higher Education (Kemenristek-Dikti), Republic of Indonesia.

\section{REFERENCES}

Ackerman R. 1997. The nest environment and the embryonic development of sea turtles. In: Lutz P, Musick J (eds). The Biology of Sea Turtles. CRC Press, Boca Raton, FL. 
Anan Y, Kunito T, Watanabe I, Sakai H, Tanabe S. 2001. Trace element accumulation in hawksbill turtles (Eretmochelys imbricata) and green turtles (Chelonia mydas) from Yaeyama Islands, Japan. Environ Toxicol Chem 20 (12): 2802-2814. DOI: 10.1002/etc.5620201220.

Beck KM, Fair P, McFee W, Wolf D. 1997. Heavy metals in livers of bottlenose dolphins stranded along the South Carolina coast. Mar Pollut Bull 34 (9): 734-739.

Bicho R, Joaquim N, Mendonca V, Al Kiyumi A, Mahmoud IY, Al Kindi A. 2006. Levels of heavy metals and antioxidant enzymes in green turtle (Chelonia mydas) in the Arabian Sea, Sultanate of Oman. Twenty-Sixth Annual Symposium on Sea Turtle Biology and Conservation. International Sea Turtle Society, Athens, Greece.

Binckley CA, Spotila JR, Wilson KS, Paladino FV. 1998. Sex determination and sex ratios of Pacific leatherback turtles, Dermochelys coriacea. Copeia 1998: 291-300.

Booth DT, Astill K. 2001. Incubation temperature, energy expenditure and hatchling size in the green turtle (Chelonia mydas), a species with temperature-sensitive sex determination. Aust J Zool 49 (4): 389-396.

Broderick AC, Godley BJ, Hays GC. 2001. Metabolic heating and the prediction of sex ratios for green turtles (Chelonia mydas). Physiol Biochem Zool 74: 161-170. DOI: 10.1086/319661.

BSN [Badan Standarisasi Nasional]. 2009. Batas Maksimum Cemaran Logam Berat dalam Pangan. Standar Nasional Indonesia SNI 7387: 2009. [Indonesian]

Cardellicchio N, Decataldo A, Di Leo A, Giandomenico S. 2002. Trace elements in organs and tissues of striped dolphins (Stenella coeruleoalba) from the Mediterranean Sea (Southern Italy) Chemosphere 49 (1): 85-90. DOI: 10.1016/S0045-6535(02)00170-4

Caurant F, Bustamente P, Bordes M, Miramand P. 1999. Bioaccumulation of cadmium, copper, and zinc in some tissues of three species of marine turtles stranded along the French Atlantic coasts. Mar Pollut Bull 38 (12): 1085-1091

Chan EH, Liew HC. 1995. Incubation temperatures and sex-ratios in the Malaysian leatherback turtle (Dermochelys coriacea). Biol Conserv 74 (3): 169-174.

Chevalier J, Godfrey MH, Girondot M. 1999. Significant difference of temperature-dependent sex determination between French Guiana (Atlantic) and Playa Grande (Costa-Rica, Pacific) leatherbacks (Dermochelys coriacea). Annales des Sciences Naturelles-Zoologie et Biologie Animale 20 (4): 147-152.

Clarkson TW. 1990. Human health risks from methylmercury in fish Environ Toxicol Chem 9 (7): 957-961.

Clarkson TW. 1993. Mercury: Major issues in environmental health Environ Health Perspect 100: 31-38. DOI: 10.1289\%2Fehp.9310031

Cortez-Gomez AA, Morcillo P, Guardiola FA, Espinosa C, Esteban, MA, Cuesta A, Girondot M, Romero D. 2018. Molecular oxidative stress markers in olive ridley turtles (Lepidochelys olivacea) in their relation to metal concentrations in wild populations. Environ Pollut 233:156167. DOI: 10.1016/j.envpol.2017.10.046

Davenport J, Wrench J. 1990. Metal levels in a leatherback turtle. Ma Pollut Bull 21: 40-41.

dei Marcovaldi MAG, Lopez-Mendilaharsu M, Santos AS, Lopez GG, Godfrey MH, Tognin F, Baptistotte C, Thome JC, Dias ACC, de Castilhos JC, Fuentes MMPB. 2016. Identification of loggerhead male producing beaches in the south Atlantic: Implications for conservation. J Exp Mar Biol Ecol 477: 14-22. DOI: 10.1016/j.jembe.2016.01.001

Dutton PH, Whitmore CP, Mrosovsky N. 1985. Masculinization of leatherback turtle Dermochelys coriacea hatchlings from eggs incubated in styrofoam boxes. Biol Conserv 31 (3): 249-264.

EPA, Environmental Protection Agency. 2001. Mercury Update: Impact on Fish Advisories. EPA-823-F-01-011, U.S. Environmental Protection Agency, Washington, DC.

Fuentes MMPB, Monsinjon J, Lopez M, Lara P, Santos A, dei Marcovaldi MAG, Girondot M. 2017. Sea ratio estimates for species with temperature-dependent sex determination differ according to the proxy used. Ecol Model 365: 55-67. DOI: 10.1016/j.ecolmodel.2017.09.022.

Gardner SC, Fitzgerald SL, Acosta Vargas B, Mendez Rodriguez L. 2006. Heavy metal accumulation in four species of sea turtles from the Baja California Peninsula, Mexico. Biometals 19 (1): 91-99.

Georges A, Doody S, Beggs K, Young J. 2004. Thermal Models of TSD under Laboratory and Field Conditions. Temperature-dependent Sex Determination in Vertebrates. Smithsonian Books, Washington, DC.

Georges A, Limpus C, Stoutjesdijk R. 1994. Hatchling sex in the marine turtle Caretta caretta is determined by proportion of development at temperature, not daily duration of exposure. J Exp Zool 270 (5): 432 444.
Girondot M, Kaska Y. 2014. A model to predict the thermal reaction norm for the embryo growth rate from field data. J Therm Biol 45:96-102. DOI: $10.1016 /$ j.jtherbio.2014.08.005

Girondot M, Ben Hassine S, Sellos C, Godfrey M, Guillon JM. 2010. Modelling thermal influence on animal growth and sex determination in reptiles: being closer to the target gives new views. Sex Dev 4 (1-2): 29-38. DOI: $10.1159 / 000280585$

Girondot M. 2014. Phenology: Tools to Manage a Parametric Function that Describes Phenology. R Package Version 3.63.

Godfrey MH, Mrosovsky N, Barreto R. 1996. Estimating past and present sex ratios of sea turtles in Suriname. Can J Zool 74 (2): 267-277.

Godley BJ, Broderick AC, Glen F, Hays GC. 2002. Temperature-dependent sex determination of Ascension Island green turtles. Mar Ecol Prog Ser 226: 115-124. DOI: 10.3354/meps226115

Godley BJ, Thompson DR, Furness RW. 1999. Do heavy metal concentrations pose a threat to marine turtles from the Mediterranean Sea? Mar Pollut Bull 38 (6): 497-502.

Gordon AN, Pople AR, Ng J. 1998. Trace metal concentrations in livers and kidneys of sea turtles from south-eastern Queensland, Australia. Mar Freshw Res 49 (5): 409-414.

Grandjean P, Weihe P, Needham LL, Burse VW, Patterson DG, Sampson EJ. 1995. Relation of a seafood diet to mercury, selenium, arsenic, and polychlorinated biphenyl and other organochlorine concentrations in human milk. Environ Res 71 (1): 29-38.

Joseph J, Ali SN, Hing LS. 2014. Heavy metal composition in Green Turtle (Chelonia mydas) eggs from nesting beaches in Peninsular Malaysia. Asian J Conserv Biol 3 (1): 83-87.

Kaska Y, Downie R, Tippett R, Furness RW. 1998. Natural temperature regimes for loggerhead and green turtle nests in the eastern Mediterranean. Can J Zool 76 (4): 723-729.

Khristoforova NK, Kozhenkova SI. 2002. The use of the brown algae Sargassum spp. in heavy metal monitoring of the marine environment near Vladivostok, Russia. Ocean Polar Res 24 (4): 325-329.

Kobayashi N, Okamura H. 2004. Effects of heavy metals on sea urchin embryo development. Chemosphere 55 (10): 1403-1412. DOI: 10.1016/j.chemosphere.2003.11.052

Mendez L, Alvarez-Castaneda ST, Acosta B, Sierra-Beltran AP. 2002. Trace metals in tissues of gray whale carcasses (Eschrichtius robustus) from the north Pacific Mexican coast. Mar Pollut Bull 44 (3): 217-221.

Merchant-Larios H, Ruiz-Ramirez S, Moreno-Mendoza N, MarmolejoValencia A. 1997. Correlation among thermosensitive period, estradiol response, and gonad differentiation in the sea turtle Lepidochelys olivacea. Gen Comp Endocrinol 107 (3): 373-385. DOI: 10.1006/gcen.1997.6946

Miller JD, Limpus CJ. 1981. Incubation period and sexual differentiation in the green turtle Chelonia mydas. Proceedings of the Melbourne Herpetological Symposium. The Zoological Board of Victoria, Melbourne.

Morreale SJ, Ruiz GJ, Standora EA. 1982. Temperature-dependent sex determination: Current practices threaten conservation of sea turtles. Sci 216 (4551): 1245-1247.

Mrosovsky N, Dutton PH, Whitmore CP. 1984. Sex ratios of two species of sea turtle nesting in Suriname. Can J Zool 62 (11): 2227-2239.

Mrosovsky N. 1988. Pivotal temperatures for loggerhead turtles (Caretta caretta) from northern and southern nesting beaches. Can J Zool 66 (3): 661-669.

Mrosovsky N. 1994. Sex ratios of sea turtles. J Exp Zool 270: 16-27.

Orłowski G, Hałupka L, Pokorny P, Klimczuk E, Sztwiertnia H, Dobicki W, Polechoński R. 2017. The pattern of distribution and interaction of metals and calcium in eggshells and egg contents in relation to the embryonic development of eggs in a small passerine bird. J Ornithol 158 (1): 297-309.

Protocol 3112-B: Metals by Cold-Vapor Atomic Absorption Spectrometry. htps://law.resource.org/pub/us/cfr/ibr/002/apha.method.3112.1992.pdf

R Development Core Team. 2018. The R Project for Statistical Computing. Version 2.14.1 http://www.r-project.org/ Downloaded on 12/22/2018. R Foundation for Statistical Computing, Vienna, Austria.

Roe JH, Sill NS, Columbia MR, Paladino FV. 2011. Trace metals in eggs and hatchlings of Pacific Leatherback turtles (Dermochelys coriacea) nesting at Playa Grande, Costa Rica. Chelonian Conserv Biol 10 (1): 3-9.

Sakai H, Ichihashi H, Suganuma H, Tatsukawa R. 1995. Heavy metal monitoring in sea turtles using eggs. Mar Pollut Bull 30 (5): 347-353.

Sakai H, Saeki K, Ichihashi H, Suganuma H, Tanabe S, Tatsukawa R. 2000. Species-specific distribution of heavy metals in tissues and organs of 
loggerhead turtle (Caretta caretta) and green turtle (Chelonia mydas) from Japanese coastal waters. Mar Pollut Bull 40 (8): 701-709.

Santidrian-Tomillo P, Robinson NJ, Fonseca LG, Quiros-Pereira W, Arauz R, Beange M, Piedra R, Velez E, Paladino FV, Spotila JR, Wallace BP. 2017. Secondary nesting beaches for leatherback turtles on the Pacific coast of Costa Rica. Lat Am J Aquat Res 45 (3): 563-571.

Shintana M, Nedi S, Tanjung A. 1980. The Concentration of Heavy Metals of $\mathrm{Pb}, \mathrm{Cu}$, and $\mathrm{Zn}$ in Eggs of Olive-ridley Turtle (Lepidochelys Olivacea) in Nesting Locations of Pariaman Town Beach, West Sumatra Province. [Doctoral Thesis]. University of Riau, Indonesia.

Standard methods for the examination of water and wastewater $22^{\text {nd }}$ edition. https://beta-static.fishersci.com/content /dam/fishersci/en_US/documents/programs/scientific/technical-documents/ whitepapers/apha-water-testing-standard-methods-white-paper. pdf.

Standard methods for the examination of water and wastewater. 3030 Preliminary Treatment of Samples (2017) https://www.standardmethods.org/doi/abs/10.2105/SMWW.2882.041.

Standard methods for the examination of water and wastewater. Manual Hydride Generation Atomic Absorption Spectrometric Method. https://law.resource.org/pub/us/cfr/ibr/002/apha.method.3114.1992.pdf.

Standard methods for the examination of water and wastewater. Metals by Flame Atomic Absorption Spectrometry. https://law.resource.org/pub/us/cfr/ibr/002/apha.method.3111. 1992. pdf.

Storelli MM, Ceci E, Marcotrigiano GO. 1998. Distribution of heavy metal residues in some tissues of Caretta caretta (Linnaeus) specimens beach along the Adriatic Sea (Italy). Bull Environ Contam Toxicol 60: 546552.

Stubbs JL, Kearney MR, Whiting SD, Mitchell NJ. 2014. Models of primary sex ratios at a major flatback turtle rookery show an anomalous masculinizing trend. Clim Change Response 1 (1): 1-17.

Tapilatu RF, Tiwari M. 2007. Leatherback turtle, Dermochelys coriacea hatching success at Jamursba-Medi and Wermon beaches in Papua, Indonesia. Chelonian Conserv Biol 6: 154-158.

Tapilatu RF, Dutton PH, Tiwari M, Wibbels T, Ferdinandus HV, Iwanggin WG, Nugroho BH. 2013. Long-term decline of the western Pacific leatherback, Dermochelys coriacea; A globally important sea turtle population. Ecosphere 4 (2): 1-15.

Tapilatu RF. 2014. The conservation of western Pacific Leatherback Sea Turtle (Dermochelys coriacea) at Bird's Head Peninsula. Papua Barat, Indonesia. [Dissertation]. University of Alabama at Birmingham, United States.

Tapilatu RF, Ballamu F. 2015. Nest temperatures of the Piai and Sayang Islands green turtle (Chelonia mydas) rookeries, Raja Ampat Papua,
Indonesia: Implications for hatchling sex ratios. Biodiversitas 16 (1): 102-107. DOI: 10.13057/biodiv/d160114

Tapilatu RF, Wona H, Siburian RHS. 2016. Hasil Analisis Sample Telur. Universitas Papua, Manokwari. [Indonesian]

Tapilatu RF. 2017. Monitoring and conservation of Western Pacific leatherback (and other marine turtles) Nesting population at Etna Bay of Kaimana, West Papua-Indonesia. Report to Conservation International (CI) Indonesia Grant \# 6001289, 14p.

Tapilatu RF, Wona H, Batubara PP. 2017. Status of sea turtle populations and its conservation at Bird's Head Seascape, Western Papua, Indonesia. Biodiversitas 18 (1): 129-136. DOI: 10.13057/biodiv/d180118

Tapilatu RF. 2017. The evaluation of nest relocation method as a conservation strategy for saving sea turtle populations in the North Coast of Manokwari-Papua Barat Province-Indonesia. Ecol Environ Conserv 23 (4): 1816-1825.

Tapilatu RF, Wona H, Siburian RHS. 2020. Data on Environmental Contaminants in Sea Turtle Eggs at Venu Island, Kaimana-West Papua Indonesia. Data in Brief (DiB), 105778.

Tilley D, Ball S, Ellick J, Godley BJ, Weber N, Weber SB, Broderick AC. 2019. No evidence of fine-scale thermal adaptation in green turtles. $J$ Exp Mar Biol Ecol 514-515: 110-117. DOI: 10.1016/j.jembe.2019.04.001

Ullrich S, Tanton T, Abdrashitova S. 2001. Mercury in the environment: A review of the factors affecting methylation. Crit Rev Environ Sci Technol 31 (3): 241-293.

Vazquez GF, Reyes MC, Fernandez G, Aguayo JEC, Sharma VK. 1996. Contamination in marine turtle (Dermochelys coriacea) egg shells of Playon de Mexiquillo, Michoacan, Mexico. Bull Environ Contam Toxicol 58 (2): 326-333. DOI: 10.1007/s001289900338

WHO, World Health Organization. 2003. Summary and Conclusions of the 61st Meeting of the Joint FAO/WHO Expert Committee on Food Additives. World Health Organization, Rome, Italy.

Wibbels T. 2003. Critical approaches to sex determination in Sea Turtles. In: Lutz PL, Musick JA, Wyneken J (eds). The Biology of Sea Turtles Volume II. CRC Press, Boca Raton, Florida.

Wyneken J, Lolavar A. 2015. Loggerhead sea turtle environmental sex determination: Implications of moisture and temperature for climate change-based predictions for species survival. J Exp Zool. Part B: Mol Dev Evol 324 (3): 295-314. DOI: 10.1002/jez.b.22620

Yntema CL, Mrosovsky N. 1982. Critical periods and pivotal temperatures for sexual differentiation in loggerhead sea turtles. Can J Zool 60 (5): 1012-1016. 